\title{
CONSTRUÇÕES DISCURSIVAS E VIOLÊNCIA CORPORAL EM AS PARCEIRAS, DE LYA LUFT
}

\section{Jerzuí Tomaz}

Falo do estranho que somos: nobres e vulgares, sonhadores e consumidores, soprados de esperança e corroídos de terror, generosos e tantas vezes mesquinhos...

Lya Luft

Resumo: O artigo objetiva analisar, utilizando-se o referencial teórico psicanalítico, as modulações da voz narrativa em As parceiras, uma vez que se sustenta a hipótese de que a escritora constrói uma estética da violência corporal que se presentifica em todas as personagens femininas. Palavras-chave: feminino; discurso; corpo erógeno; sexualidade; desejo

A gaúcha de ascendência germânica Lya Luft tem se apresentado no cenário da Literatura Brasileira de autoria feminina, lado a lado com os conterrâneos Moacyr Scliar, Luís Fernando Veríssimo, João Gilberto Noll, Tabajara Ruas, Charles Kiefer, Luís Antônio de Assis Brasil, Sérgio Faraco, dentre outros.

Sua obra abrange dezoito livros, entre crônica, ensaio, poesia, prosa. A crítica tem destacado na escritura luftiana um "modo feminino" - vale assinalar que aqui não se aponta para nenhum tipo de essencialismo - de ver e sentir o mundo, configurado através de um adequado domínio da técnica narrativa. Mais do que uma modalidade discursiva contemporânea é a relação da escrita com o corpo que se destaca nesta autora. A dimensão corporal, feminina, da sua escritura alia-se à preocupação de renovação da linguagem literária, de restauração de um sentido poético.

Para caracterizar suas personagens-narradoras, Lya Luft lança mão do estranhamento (o Unheimlich freudiano), inscrevendo o feminino - entendido como um efeito de linguagem, resultante da

1 Doutoranda do PPGLL/Ufal e professora do Centro de Educação da mesma universidade. 
inserção do sujeito no mundo da cultura - na categoria do "excêntrico", isto é, de tudo aquilo que é marginalizado por uma ideologia dominante. Esta escritora coloca-se, pois, como ponto de referência nos estudos de literatura de autoria feminina, dando continuidade à linhagem iniciada por Clarice Lispector (sondagem introspectiva) ao problematizar, sobretudo, a condição da mulher.

A partir do romance de estréia As parceiras (1980), a configuração discursiva do universo feminino luftiano versa sobre temas recorrentes, tais como o desejo, a morte, a sexualidade, o aprisionamento ao fado/destino, a maternidade fracassada, os jogos de poder, o que se faz acompanhar de inscrições corporais específicas, observando-se um corpo marcado/violentado pela dor e conversibilidade histérica (vínculo com a estrutura psíquica e social que o determina).

Destaca-se, na produção literária de Lya Luft, uma dupla inscrição, na qual o social e o estilístico se reforçam mutuamente, apontando para a urgência de encontrar novas formas de convivência entre homens e mulheres e, ao mesmo tempo, a busca irrenunciável de renovação das convenções narrativas.

Este artigo objetiva identificar os traços configuradores do discurso da personagem-narradora Anelise, protagonista de As parceiras, analisando-se as modulações da voz narrativa desta no texto literário em referência, uma vez que se sustenta a hipótese de que a escritora gaúcha constrói, minuciosamente, uma estética da violência corporal que irá atingir todas as personagens femininas.

Percebe-se que a urdidura dos seres ficcionais se reveste de uma grande complexidade, inexistindo perfis estanques, o que resulta da ambigüidade que caracteriza o texto luftiano. Desta forma, cada personagem, a partir do seu ponto de vista, procura pontuar/decifrar

2 O sujeito "ex-cêntrico" aqui teorizado deriva do sujeito do pósestruturalismo, com uma identidade desprovida de essência e que se constitui a partir das narrativas tecidas pelas diversas culturas. Cf. COSTA, Cláudia de Lima. Sujeitos Ex/Cêntricos: explorando as fronteiras do feminismo, 1996, p. 51-59. 
enigmas, demarcando efeitos de diferença/semelhança em relação ao universo masculino.

As questões intrínsecas à narratividade da produção literária de Lya Luft - a constituição do sujeito, seus mecanismos psíquicos, o assujeitamento deste à ordem simbólica e os "jogos de poder" transmutados em violência corporal - serão investigados utilizando-se como referencial teórico basilar a psicanálise (Freud e Lacan) e teorias convergentes, objetivando-se um cruzamento interdisciplinar de olhares.

A escolha da ciência psicanalítica como bússola teórica deste ensaio deve-se à descoberta freudiana de que o inconsciente obedece a leis análogas às leis lingüísticas, o que revela a supremacia da função simbólica em relação ao falasser (ser de linguagem). No entanto, é interessante que se faça menção ao uso indevido que a psicanálise pode assumir no deciframento das produções literárias, uma vez que, no diálogo literatura/psicanálise, não se trata de humanos, portadores de inconsciente, memória e traumas de infância, mas de construções fictícias, elaboradas pelo escritor/a. Dito de outro modo, é a literatura e a lingüística que ensinam sobre o inconsciente, e não o contrário.

Assim, evidencia-se que é o romance que, através de sua forma, "solicita" uma determinada teoria para tentar elucidar questões literárias. Sabe-se que a literatura se atrela aos parâmetros de uma forma, projeto estético e composição, isto é, a ficção é indissociável de uma estrutura/composição estilística, pois a forma transmuta-se em conteúdo socialmente estruturado.

No que se refere ao lugar do crítico, a desconstruçãodessacralização da arte literária possui, como uma de suas balizas teóricas, as proposições sustentadas pelos pós-estruturalistas Foucault, Lacan, Deleuze e Derrida -, que apregoam a exclusão do autor do texto literário, trazendo à cena o leitor, cúmplice silencioso que é capturado pelo enigma da escritura.

De acordo com esta escola de pensamento, a obra nada diz; quem produz significação é o leitor, com o seu "trabalho inconsciente" de leitura. Denota-se, a partir disto, uma postura teórica diversa, na qual se desvia a noção de sujeito/autor para a de produtividade textual, evidenciando-se uma fratura na atribuição de sentido - incompletude do recorte analítico -, já que não pode existir 
pretensão de totalidade da interpretação, ou seja, todo texto está aberto a diferentes leituras de acordo com o "horizonte hermenêutico" de cada leitor.

Compagnon, por sua vez, acredita que "a leitura tem a ver com empatia, projeção, identificação. Ela maltrata obrigatoriamente o livro, adaptando-o às preocupações do leitor" "3. A partir desta teorização, uma considerável "liberdade" é concedida ao leitor na interpretação já que este imprime sua influência, resistência e forma de recepção aos pontos obscuros da produção literária, uma vez que a "obra aberta" viabiliza um ponto de vista errante sobre o texto. Perrone-Moisés (1998) corrobora esta proposição teórica ao apontar para a estética da recepção, que possibilita a crença em valores relativos e transitórios, portadores de "verdades" que oscilam (inexistência de verdade hegemônica).

Deste modo, o fim das utopias totalizantes sinaliza para a complexidade das contradições que existem dentro do já estabelecido, viabilizando a "fuga" ao controle do poder vigente, ideológico e literário, que questiona valores tradicionais.

Não seria arriscado afirmar que As parceiras se encontra em sintonia com tais formas de ler e interpretar a literatura de autoria feminina. Lya Luft constrói personagens-narradoras contidas pelas adversidades e aparentemente frágeis. No entanto, oferece-lhes voz e possibilidade para a construção, quem sabe, de utopias negativas ${ }^{4}$ como as propostas nos romances de Margaret Atwood.

A escritora do romance em análise revela a opacidade da vivência psíquica que se expressa através do discurso, urdindo um universo temático que denuncia os estereótipos sexuais da tradição. A prosa ficcional marcadamente introspectiva - pode-se pensar no fluxo de consciência de Anelise - põe em questão o tempo que norteia a

3 COMPAGNON, Antoine. O demônio da teoria: literatura e senso comum. Tradução de Cleonice Paes B. Mourão. Belo Horizonte: UFMG, 1999 , p. 143.

4 Utopia negativa ou distopia refere-se a um lugar onde nada, ou quase nada, está bem. Os exemplos ficcionais mais conhecidos são $O$ admirável mundo novo, de Aldous Huxley, e 1984, de George Orwell. 
personagem-narradora, num constante imbricamento entre presente e passado.

Dentro de uma tessitura textual permeada pela dor, loucura e morte, Anelise, como muitas das construções fictícias luftianas, é uma mulher adulta, com um casamento desfeito, que se isola em um chalé - também é recorrente na obra de Lya Luft o "enclausuramento" das personagens femininas - para "passar o filme" da própria vida. Claramente distópica pela via da supressão do desejo ${ }^{5}$, ela relata sua problemática existencial a partir de um mundo psíquico fragmentado.

A densa temática do romance aponta para um sombrio mistério a partir do título As parceiras, pois, de acordo com a fala da protagonista, a vida é encenada como um jogo de azar, tabuleiro de xadrez que simboliza as forças antagônicas que se opõem na luta pela vida - Eros e Thânatos -, enquadrando uma situação de conflito, um cenário de oposições, de combates. No dizer de Anelise: "éramos um bando de mulheres malsinadas, mas só mais tarde eu entenderia isso também" (p. 36) ${ }^{6}$. A busca de suas "raízes" revela o traço trágico ${ }^{7}$ da personagem, aparentemente presa a um destino inexorável, uma vez que, de acordo com sua percepção, o núcleo familiar do qual faz parte é composto de "seres silenciosos, nunca havia trégua, nunca se podia parar, senão o inenarrável brotava, punha de fora um dedo ameaçador" (p. 124).

A trama romanesca desenvolve-se em torno da figura de Catarina (representação do interdito), avó de Anelise, descendente de alemães, uma menina "loura e delicada" que aos catorze anos é entregue pela mãe a um pretendente que a toma como esposa, um

5 Desejo, neste contexto, refere-se à falta que se inscreve na palavra, resultante da marca do significante sobre o ser de linguagem. Para Lacan, o desejo é "a metonímia da falta a ser".

6 Os trechos referentes a esta obra serão indicados somente pelo número da página.

7 O trágico pode ser pensado como uma espécie de essência, de conteúdo profundo que impregna a condição humana em qualquer tempo da história, conteúdo que aponta para um conhecimento adquirido através da dor. Cf. MEICHES, Mauro. A travessia do trágico em análise, 2000, p. 22. 
homem que possui "virilhas em fogo", ou seja, "jogaram com ela um jogo sujo. Não podia mesmo agüentar" (p.11). A nominalização jogarjogo, presente neste fragmento, explicita a ênfase no desamparo da personagem feminina, uma vez que esta é "jogada" no embate com o mundo. Observa-se que o privilégio anatômico masculino converte-se em privilégio humano e social, já que "o destino foi zeloso: caçou-a pelos quartos do casarão, seguia-a pelos corredores, ameaçou arrombar os banheiros chaveados como arrombava dia e noite o corpo imaturo" (p. 14). A repetição da consoante $r$, letra do áspero, do gutural, próprio daquilo que fere mas não aniquila, possibilitando uma sobrevida, ratifica o campo semântico da aspereza, recurso da linguagem utilizado para anunciar o que virá a seguir. A simbologia da chave, por sua vez, arremete para a figura do senhor, do iniciador, daquele que detém o poder, bem como o mistério/enigma a ser decifrado ${ }^{8}$.

É interessante ressaltar que a voz de Catarina não se inscreve na narrativa romanesca, mas os relatos de passagens de sua vida são constantemente mencionados no monólogo interior de Anelise, ou seja, aquela que dá origem à genealogia de mulheres "doidas e sozinhas" não alcança o estatuto de sujeito, de acordo com a teoria lacaniana, pois

O eu se constitui inicialmente numa experiência de linguagem, em referência ao $t u$, e isso, numa relação em que o outro lhe manifesta o quê? - ordens, desejos, que ela deve reconhecer, do seu pai, da sua mãe, dos seus educadores, ou dos seus pares e camaradas (LACAN, 1994, p.193 - grifo do autor).

Após sucessivas violentações, abandonada pela mãe que retorna para a Alemanha e não atende aos seus apelos, resta a Catarina Von Sassen construir um mundo branco, cor da pureza, da passagem, da morte e do luto ${ }^{9}$ e refugiar-se em "um quarto de menina, aquele.

8 CHEVAlIER, Jean \& GHEERBRANT, Alain. Dicionário de símbolos: mitos, sonhos, costumes, gestos, formas, figuras, cores, números. Tradução de Vera da Costa e Silva et al. 11. ed. Rio de Janeiro: José Olympio, 1997, p. 233.

9 Op. cit., p. 141, passim. 
Limpo. Inocente" (p.12). A antífrase utilizada por Lya Luft insinua a violência simbólica e corporal que se insere nas práticas discursivas já que somos atravessados e constituídos por signos lingüísticos -, recurso mimético empregado para a elaboração textual, uma vez que a mimese é um conhecimento próprio de cada escritor, é a maneira pela qual ele constrói e habita o seu mundo ${ }^{10}$.

Se é um fato que o possível deciframento de uma obra literária nos chega pela trama, pela organização artística do conteúdo, vale ressaltar a circularidade da linguagem (auto-referência) presente no romance luftiano, o que se evidencia na rememoração de Anelise, onde se insinua, reiteradamente, começo e fim, vida e morte, aniquilamento e sobrevivência psíquica: "Mas tenho muito que fazer: descobrir como tudo começou, como acabou. Por que acabou. Se dou com a ponta errada do fio, se descubro o lance perverso da jogada, a peça de azar, quem sabe consigo sobreviver (p. 18)".

A teorização psicanalítica postula que a ligação entre os seres de linguagem somente é possível através da palavra, pois a possibilidade simbólica (abertura das cadeias significantes) é o que pode livrar o indivíduo de significações cristalizadas e mortificantes, uma vez que, como afirma Moustapha Safouan, "entre dois sujeitos não há senão a palavra ou a morte, a salvação ou a lápide"11.

Assim, Anelise, ao buscar uma fala plena, pode ser vista como a antítese de Catarina, a excêntrica moradora do sótão, sempre envolta em roupas brancas e cercada de solidão e medo. De acordo com o relato da neta, esta mulher, entre gritos e escândalos,

[...] teve alguns abortos e, nos intervalos, três filhas: Beatriz, que chamávamos Beata. Dora, a pintora. Norma, a mais nova, a minha mãe. Fisicamente, a que se parecia com Catarina. Mais de vinte anos depois, viria Sibila, concebida e parida no sótão. Melhor não tivesse vindo: Bila, Bilinha, retardada e anã (p. 15).

10 COMPAGNON, op.cit., 1999, p. 127.

11 SAFOUAN, Moustapha. A palavra ou a morte: como é possível uma sociedade humana? Tradução de Regina Steffen. São Paulo: Papirus, 1993, p. 53. 
A partir dessa descrição, pode-se pensar que Catarina, vítima de um assujeitamento simbólico, é a matriz de uma galeria de figuras femininas, transformando-se na Parca-Moira, aquela que tece e corta o fio da vida, já que, na visão de Anelise, "a peça mais importante sempre fora minha avó, que eu só vira uma vez no sótão recendendo a alfazema" (p. 49).

A reclusão de Anelise no chalé, na tentativa de reescrever o texto da própria vida, num claro descompasso entre tempo cronológico (diários) e tempo da narrativa, encarna a ambivalência enraizada na condição humana e revela-nos que, por mais que o sujeito fale de si mesmo, ele é, sobretudo, o seu insondável mistério: "a palavra má. As palavras inquietantes" (p. 39).

O silêncio carregado de sentido da obra literária solicita de um crítico que, no contato amoroso com o texto, assuma a postura de um exegeta, de um explorador incansável, que desvela secretas vibrações. Lya Luft, como artífice de uma aventura estética, induz-nos a buscar as significações que se insinuam entre o dito e o interdito, levando-nos a crer que a literatura é passível de transcender o instante e a morte, um dos últimos tabus culturais e um dos primeiros da humanidade.

A competência narrativa luftiana e seu potencial transfigurador da realidade concreta apontam, através do discurso de Anelise, para os modos de subjetivação predominantes na cultura, pois, antes de ser racional (império do Logus), o humano é falante, e se pode asseverar que as mudanças de formas discursivas demarcam momentos de despersonalização ou de objetivação do sujeito. A fala/linguagem tanto pode ser anônima e impessoal, ressonância do Outro $^{12}$ que nos invade, como pode representar a possibilidade de humanização de um ser sem voz.

Desta forma, a dor e a diviš́o imanentes à existência materializam-se nas modulações do discurso de Anelise que, ao tematizar as idiossincrasias da condição feminina, traz à cena as heterogeneidades internas da ficção - prosa ficcional e o vaivém do

12 Para Lacan, o Outro (lê-se "grande outro") é a instância anterior e exterior ao sujeito e que, no entanto, o determina. Confunde-se com a ordem da linguagem. É o lugar do código lingüístico, tesouro dos significantes. 

DE LYA LUFT

discurso interior -, já que identifica a presença de "sombras encaixotadas, vermes aflitos no sótão, vultos na memória. Tudo o que dizemos: metáfora da mesma coisa" (p.95).

O foco narrativo em primeira pessoa, o tempo não-linear, a repetição temática aproximam o (dis)curso da personagem-narradora da associação livre tematizada na teorização psicanalítica, bem como os significantes sombras e vultos (recorrência lingüística) colocam-se como recursos estéticos que sinalizam para o indizível da linguagem, uma vez que, como postula Lacan, o inconsciente se estrutura como uma linguagem. No dizer de Schüler, na esquiva marcha da verdade, o humano descobre que "o discurso é a passagem do invisível ao visível e do visível ao invisível. Nesse ir e vir, vida e morte se tocam e se repelem em circularidade sem princípio nem fim"13.

Desta forma, numa luta agonística com as palavras, Anelise busca decifrar o enigma da própria vida, enfrentando a morte simbólica que, de acordo com a sua narrativa, "[...] entrou em mim num ferimento que jamais sarava, pois logo outra pessoa morria, e eu a enterrava naquele lugar. Até Catarina emergiu da minha memória e aninhou-se ali, sempre murmurando (p. 24 - grifo meu)".

A perda de Adélia, a amiga de infância que se atira de um penhasco, o alheamento de Norma (mãe da protagonista), o suicídio de Catarina, a aspereza da Tia "Beata", a excentricidade da Tia Dora, a deformação de Bila, retardada e anã (resto de vômito e estupro), merece uma análise sobre a estruturação do psiquismo humano o qual, de acordo com as pesquisas de Sigmund Freud, está estreitamente vinculado ao percurso da sexualidade. Vale ressaltar que sexualidade deve ser entendida como tudo o que mobiliza para a busca do prazer e redução de tensão psíquica. A partir dessa perspectiva teórica, fica fácil entender as desordens afetivas (expressas pela palavra e pelo interdito) e corporais que se manifestam no "bando de mulheres malsinadas" esboçadas pela escritora gaúcha.

13 SCHÜLER, Donaldo. Heráclito e seu (dis)curso. Porto Alegre: L \& PM, 2000, p. 213. 
De acordo como os estudos psicanalíticos, chegamos a ser o que somos através de uma inter-relação de corpos, que se dá por meio das primeiras relações afetivas estruturadas durante a infância:

$\mathrm{Na}$ teoria lacaniana, é [o] objeto original perdido - o corpo da mãe - que impulsiona a narrativa de nossas vidas, impelindo-nos à busca de substitutos para esse paraíso perdido no interminável movimento metonímico do desejo ${ }^{14}$.

Se a sexualidade humana é traumática por $\mathrm{si}^{15}$, devido à imaturidade da criança e também à inadequação dos primeiros objetos de amor e desejo (pai e mãe interditados pela lei primordial da cultura), além do que o "sexo é aquilo que não temos acesso, que está além do nosso corpo, um sexo não sabido, não conhecido, que não somos capazes de conhecer, porque falamos"16, entende-se como "Catarina sucumbiu a um fundo terror do sexo e da vida" (p.14), já que "quando o marido irrompia naquela faisa tranqüilidade, não deixava de procurar a mulher. Dava um jeito de abrirem o sótão, e, entre gritos e escândalos, emprenhava Catarina outra vez (p. 15)".

Esta, ao transformar-se na louca do sótão - tema recorrente na literatura de autoria feminina: associação loucura/mulher -, conceituando-se a "loucura" como o produto de um contexto psíquico e social, evidencia-se a violência corporal falocêntrica que se dilui nas personagens do romance.

O encanto e o terror que a leitura da obra luftiana provoca mostra-nos que o estético dá resposta ao social por meio da pluralidade de agenciamentos discursivos, uma vez que as "mulheres perdedoras", urdidas por Lya Luft, transitam entre as fronteiras da morte e os limites da vida, à beira de abismos interiores de culpa e desejo.

14 EAGLEATON, Terry. Teoria da literatura: uma introdução. Tradução de Waltensir Dutra. São Paulo: Martins Fontes, 1983, p. 1999 - grifo meu.

15 JULIEN, Philippe. A feminilidade velada: aliança conjugal e feminilidade. Tradução de Celso Pereira de Almeida. Rio de Janeiro: Companhia de Freud, 1997, p. 6.

16 CORRÊA, Ivan. A escrita do sintoma. Recife: CEF, 1997, p. 73. 

DE LYA LUFT

As metáforas literárias que a autora utiliza produzem fortes imagens psíquicas, a saber, "casamento era para ela [Catarina] a noção difusa de abraços e beijos demorados, e alguma coisa mais, assustadora. Algo de que nunca falavam direito. Como as doenças e a morte" (p.13 - grifo meu).

Tal qual Ariadne, em busca do fio que a livra da morte, Anelise busca por meio da "deriva" do (dis)curso encontrar uma saída diante do sinistro jogo das Parceiras (Vida versus Morte), ou seja, impõe-se a neta de Catarina a escolha entre situar-se como mais uma peça no enredo do romance familiar protagonizado por "mulheres vitimadas" ou enfrentar as sombras que cercam a sua existência. A partir deste impasse, a personagem-narradora busca assenhorear-se dos conteúdos do seu inconsciente: "Acho que agora estou assim. Um corpo sem memória, feito sótão cheio de moradores esquisitos. Ossadas, flores, cartas, horas de amor, delírio e morte. E a esperança, bruxa fantasiada de anjo-da-guarda companheira e traidora (p. 112)".

O corpo a que se faz referência deve ser entendido como o corpo erógeno, situado para além do físico-anatômico, que nada mais é do que o corpo do desejo, apreendido como pura representação psíquica. De acordo com Grosz, trata-se do "corpo como objeto social e discursivo, um corpo vinculado à ordem do desejo, do significado e do poder""

A dor, a devastação e a desordem que incidem sobre o corpo de Anelise manifestam-se através do fracasso no exercício da sexualidade, marcado pelo desconhecimento/negação do desejo, pois esta crê que sua sabedoria era parca para imaginar os "horrores" que o avô fazia com a jovem esposa, que mergulha no Hades da loucura como forma de sobrevivência psíquica. De início, ela aposta no casamento como uma "aventura de abismo", já que "tudo em Tiago era saudável, seguro, ordenado. [...] A coragem ainda não se desgastara" (p. 83), até concluir que "sexo triste não funciona" (p. 55).

${ }^{17}$ GROSZ, Elizabeth. Corpos reconfigurados. Cadernos Pagu, Campinas, SP, n. 14, p. 77. 
O Real ${ }^{18}$ que se abate sobre a protagonista manifesta-se por meio de "crianças malformadas", ou seja, pelos sucessivos abortos:

Tive uma segunda gravidez, uma terceira. Nenhuma vez ocupei a ala da maternidade: só frutos malogrados. A cada decepção o medo crescia com a teimosia: eu tentava outra vez. [...] Mas para mim era negação da vida, era a afirmação da minha incapacidade (p. 112).

Sabe-se que a sacralização de fenômenos como o coito, a gravidez e o parto aponta para o fato de que um filho, por mais real que possa parecer, não deixa de funcionar como um objeto imaginário/objeto tampão, como o inominado que visa suprimir a angústia materna, plenificando a mãe ${ }^{19}$. Dessa forma, a gestação sempre pressupõe uma crise narcísica, acompanhada de possíveis riscos como a regressão e o desequilíbrio psíquico. No caso de Anelise, a recorrência do aborto pode se colocar como uma incapacidade desta de simbolizar o indizível do sexo, tornando-se uma "mulher sem sombra" 20 .

Dessa forma, se cada sexo aparece como um enigma perturbador, uma vez que uma mulher só se define como mulher diante de um homem e vice-versa, é possível concordar com Simone de Beauvoir quando esta afirma que "a sexualidade não é feita para preencher um vazio; deve ser a expressão de um ser acabado",21.

O instigante jogo textual luftiano, com a produção de tropos retóricos - elipses, antíteses, rupturas narrativas - sinaliza em As parceiras para um aparente "vazio da descendência", pois, nas personagens femininas construídas pela autora têm-se "enredos" que se registram no psiquismo, deixando marcas ou feridas jamais

18 O Real (grafa-se em maiúsculo), na teoria lacaniana, refere-se a tudo o que não pode ser simbolizado na palavra ou na escrita e, como tal, não cessa de não se inscrever. No contexto literário, tal conceituação pode ser equiparada à própria ordem do discurso.

19 LEMOINE-LUCCIONI, Eugènie. A mulher ... não-toda. Tradução de André Praga. Rio de Janeiro: Revinter, 1995, p. 21.

20 Op. cit., p. 27.

21 BEAUVOIR, Simone de. O segundo sexo. Tradução de Sérgio Milliet. 2.ed. Rio de Janeiro: Nova Fronte in. 1 yo vol. 1, p. 265. 
DE LYA LUFT

cicatrizadas, com a conseqüente inscrição destas no discurso e no corpo. Por meio do monólogo interior de Anelise, sabe-se que esta sente "o corpo tenso, a alma estrangulada" (p. 112); "me arrasto até o banheiro e vomito violentamente minha dor, minha revolta, água amarga e lixo da vida" (p. 130). No que se refere à Catarina, sabe-se, através da personagem narradora, que "a avó vomitava quando o marido saía de cima dela" (p. 112).

O jorro narrativo de Lya Luft, abrindo espaço para o lugar da errância poética, elabora o campo semântico da insistência, da sobrevida. Isto se evidencia, também, na descrição de Beatriz, já que "tia Beata dava até um abraço pontudo, cotovelos magros apoiando no peito da gente, para não encostar. Nada de contatos" (p. 36). O "abraço pontudo", a "secura" do corpo indicam a agressão como defesa, evitação, características do arriscado "jogo da vida".

Beata, a rezadeira, roupa severa, cabelo curto, é designada como a viúva virgem, pois fora casada apenas três semanas, devido ao fato de que

O marido se suicidara, diziam que fora para não cumprir os deveres conjugais. Não saciara os ardores de tia Beata. Faltava ao marido o que sobrara ao meu avô. Isso fora há muitos anos, mas ainda se murmurava a respeito entre amigos e empregados, num misto de piedade e ironia (p. 36).

Se a mulher pode ser pensada como "força das trevas", artifício, tagarelice e disfarce, matriz do mundo e incerto devir orgânico, pode-se compreender a hesitação masculina entre o medo e o desejo diante da fêmea; o terror do homem de ser possuído por forças incontroláveis e a vontade de captá-las, o que se reflete no tabu e nos mitos da virgindade ${ }^{22}$; virgindade "forçada" (espírito versus carne) que será o destino de Beata. Mulher que se coloca numa dialética cruzada entre o desejo e a morte, já que impõe a si mesma a proibição do exercício da sexualidade, ao recusar a busca do apelo penetrante do sexo masculino. Beata enrijece o corpo, amordaça a palavra e recalca o desejo, pois sabe-se que "é sempre na juntura da 
fala, no nível da aparição, de sua emergência, de sua surgição que se produz a manifestação do desejo. O desejo surge no momento em que se encarna numa palavra, surge com o simbolismo ${ }^{23}$.

Michel Foucault, no texto $O$ que é um autor? (1992), denuncia como o Ocidente constrói sua concepção de desejo e estrutura "disciplinas" e "estratégias de policiamento", reafirmando que o sujeito se constitui no enfrentamento da alteridade, que é o que permite ou não a instauração da discursividade, via da expressão desejante.

Observa-se que o tipo de construção textual proposto por Lya Luft inscreve-se como um traço da modernidade literária - deflagrada por Baudelaire no século XIX - no qual se constroem palimpsestos literários, se costuram fragmentos textuais, gerando a narrativa interior de personagens, tão entrecortada quanto a memória destas, e impregnada de traços de lirismo. A partir desse ângulo, pode-se sustentar que a narrativa romanesca moderna corresponde a uma expressão da experiência contemporânea, situada frente a uma realidade e freqüentemente contra esta mesma realidade.

O saber advindo da psicanálise, que nada mais é que o saber dos mecanismos desejantes, confronta-nos com a tragédia da linguagem e sua função constituinte do humano. Octavio Paz, por sua vez, ao ressaltar a virtude metafórica da cadeia lingüística, lembra-nos que somente a linguagem é capaz de presentificar o outro ${ }^{24}$. Corroborando esta assertiva, a arquitetura do romance luftiano esboça personagens masculinos impotentes, não nomeados, falos ${ }^{25}$ decaídos. Como ilustração têm-se o avô, "um velho porco", Lauro/Lalo, o filho vegetal de Anelise, Otávio (primo da protagonista), fragilizado e dominado pela mulher (a "bruxa ruiva") e Tiago, o "marido irmão" da

23 LACAN, Jacques. O eu na teoria de Freud e na técnica da psicanálise. Tradução de Marie C. L. Penot e Antônio Quinet. 4. ed. Rio de Janeiro: Jorge Zahar, 1995, p. 294.

24 PAZ, Octavio. Signos em rotação. Tradução de Sebastião Uchoa Leite. São Paulo: Perspectiva, 1996, p. 102.

25 O falo é o símbolo do sexo masculino; tomado na lógica do inconsciente, é o objeto do desejo da mãe. 
personagem-narradora. Tais ilustrações reafirmam que "não há nada que escape à potência nomeadora da linguagem"26.

A literatura, que é antes de tudo littera, letra, inscrição, evidencia que a estrutura textual limita a significação de acordo com os elementos que se corporificam na linguagem literária. Assim, a obra literária pode ser pensada como assujeitamento e subversão do código lingüístico, devido ao fato de que chegamos tarde na cultura.

Deste modo, a trama romanesca urdida pela autora, lidando com unidade e fragmentação discursiva, aponta para os "jogos de linguagem" e para a dispersão dos signos lingüísticos propostos por Lacan. Assim, unindo-se a palavra poética e suas configurações esquemáticas (foco narrativo dentro da personagem/colocação do leitor no mundo imaginário), pretende-se assinalar que "a complexidade das personagens femininas harmoniza-se com o desenrolar de uma ficção, ancorada na coexistência de formas distintas",27.

A formalização expressiva elaborada por Lya Luft e a necessidade que se nos impõe de interrogar os enigmas textuais indicam-nos que a mulher - representada por suas personagens femininas - coloca-se num ponto de alternância entre o recalcamento e a sublimação. A escritora elege o corpo de Anelise como o palco das marcas do recalcamento, de cicatrizes psíquicas e sociais, reveladoras de nítidas marcas identitárias e mostra-nos que narrar e viver estão extremamente interligados.

Já Catarina, envolta no significante trágico, vítima de uma forca simbólica (convém relembrar que ela não tem voz na estruturação do romance), busca a "glória ambígua" das mulheres, ou seja, a morte posta sem palavras. Nicole Loraux, ao estudar a mulher no imaginário da Grécia Antiga, assevera que "a morte das mulheres confirma ou restabelece sua relação com o casamento e a

26 SAFOUAN, Moustapha. A palavra ou a morte: como é possível uma sociedade humana? Tradução de Regina Steffen. São Paulo: Papirus, 1993, p. 196.

27 PASSOS, Cleusa R. Guimarães Rosa: do feminino e suas histórias. São Paulo: Hucitec; Fapesp,2000, p. 25; grifo da autora. 
maternidade" 28 , embora Catarina, com o seu alheamento, torne-se "uma doida bonita, asseada, mansa, escrevendo e murmurando entre rendas e alfazema" (p. 53).

No entanto, sem nenhum indicativo, sobrevém o inesperado, num corpo que busca se expressar:

Um dia, o escândalo. Catarina Von Sassen, quarenta e seis anos, loura e linda, foi encontrada na cama com atitudes suspeitas com a enfermeira mocinha que diariamente lhe aplicava injeções de vitaminas e massagens para compensar a longa reclusão (p. 53).

Anelise, ao reconstituir o percurso de vida da avó, afirma: "tragédia sutil aquela: não permitiram a Catarina nenhuma salvação" (p. 54). A .personagem-narradora, ao insinuar o homoerotismo de Catarina, coloca-se também como crítica de uma "heterossexualidade compulsória", ao declarar: "choro pelos acossados, os desamados, os dúbios, que não conseguem amar dentro do esquadro alheio" (p. 55).

A despeito do aprisionamento no sótão, o que metaforiza a existência de Catarina, um imprevisto acontecimento ocorre.

Um dia, porém, sem sinal ou aviso, sem crise ou descompasso, [Catarina] abrira a porta para a sacada, o que nunca fazia. Saíra para a sacada, e jogara-se por cima da balaustra para o jardim, três andares abaixo. Caída no jardim, entre flores amassadas e morangos feito manchas de sangue era uma flor a mais, branca. O corpo quebrado, o rosto intacto, fitando a céu (p. 142; grifos meus).

O simbolismo da flor branca que a figura de Catarina evoca está associado ao amor, à harmonia, à infância (perdida e violentada, no caso da personagem em foco) e ao estado edênico ${ }^{29}$, o que denota a recorrência da figura da antífrase que a autora se utiliza para urdir os seres ficcionais. É importante também que se faça menção a aliança

28 LORAUX, Nicole. Maneiras trágicas de matar uma mulher - imaginário da Grécia Antiga. Tradução de Mário da Gama Kury. Rio de Janeiro: Jorge Zahar, 1995, p. 52.

29 CHEVAliER, Jean \& GHEERBRANT, Alain. Op. cit., 1997, p. 437. 
existente, desde tempos imemoriais, entre a mulher e a morte, pois, "a grande ceifadora é a figura invertida que faz crescerem as espigas" Outro fato que merece ser mencionado é a reiteração na poesia do Oriente e do Ocidente da metamorfose do corpo feminino em flores, frutos e pássaros, uma vez que a mãe-terra acolhe sempre os despojos dos filhos.

Partindo-se da materialidade do significante textual, vêem-se as metáforas luftianas tecidas com o intuito de elidir o referente, mas que põem em cena o ato de manifestação do ser de uma mulher aprisionada. Assim, suicidar-se assume, para Catarina, o valor de uma contundente mensagem endereçada a um mundo surdo a sua constituição desejante, já que esta fora, invariavelmente, encurralada entre o desejo e a interdição.

A indecibilidade do texto literário, no entanto, permite que se entreveja a imagem de Catarina/mulher como uma realidade marcadamente poética, fiel às "cifras do inconsciente", uma vez que nos lembra que tudo o que possuímos nos possui.

A "impureza letal da palavra" 31 aliada ao poder da forma artística produz o ato literário, que é sempre dialógico e inscreve o inegável compromisso ideológico do escritor/a, o qual se instala no enfrentamento da linguagem e reivindica o direito à expressão de uma subjetividade. No dizer da autora de As parceiras, "a literatura não emerge de águas tranqüilas: fala de minhas perplexidades enquanto ser humano, escorre de fendas onde se move algo que, inalcançável, me desafia. Escrevo sempre sobre o que não sei (1996, p. 14).

Pensando-se a literatura como algo indissociável da transgressão e da morte ${ }^{32}$, uma vez que está sempre presente o risco de subversão do código lingüístico devido aos signos de autoimplicação autorais, entende-se o texto luftiano como um espaço de desdobramento que leva o crítico a encarar o espanto em face do sentido não-unívoco da palavra poética.

30 BEAUVOIR, Simone de. O segundo sexo.Op. cit., 1980, v. 1, p. 207.

31 MACHADO, Roberto. Foucault, a filosofia e a literatura. Rio de Janeiro: Jorge Zahar, 2000, p. 146.

32

Op. cit., p. 146. 
Na tentativa de interligar discurso, violência e resistência no romance de Lya Luft, convoca-se a teorização de Alfredo Bosi, que postula que a resistência literária se dá como tema - a tentativa de transformar destino em estilo presente na fala da protagonista da obra em análise - e como processo inerente à escrita ${ }^{33}$. Como metáfora dessa tentativa da literatura de resistir e subverter o estabelecido, este autor traz à cena a flor de giesta que irrompe nas encostas do Vesúvio, cercada de lavas e cinzas. Nas palavras de Anelise, denota-se que há espaço para a resistência, pois "havia a sobrevida também: bela palavra. Todos têm sobrevida, além da hora fatal a gente agüenta ainda um ano, dois, quarenta. A trégua entre a ferida e a morte" (p. 123). Ela busca reescrever o texto/enredo da vida, ao contrário de Catarina, que não resiste ao destino cego e surdo imposto pelo outro parental e social, e tenta renunciar ao silêncio apaziguador do desejo, pois

Todo presente contém essencialmente um fator de mutação, por mais ínfimo que seja, fator que o distingue de um processo de repetição, isolando-o da nostalgia da lembrança, diferenciando-o da exangue rememoração ${ }^{34}$.

A memória corporal de Anelise, papiro no qual se inscrevem registros perceptivos (dor, aborto, frigidez, inadequação psíquica), manifesta-se nas construções discursivas referentes à lenta e dolorosa reconstituição do "romance familiar", construções estas que evidenciam um corpo em permanente inacabamento, e que intentam uma reelaboração diversa. No entre-dois que o confronto com a alteridade provoca, pode-se elaborar uma geografia íntima, entre o couro e a carne, entre feminino e masculino e, principalmente, entre corpo e palavras ${ }^{35}$.

Descrevendo-se o discurso como o locus de diferentes exílios, Lya Luft, ao entrecruzar fios de desejo e de morte, impõe-se como uma refinada intérprete do universo feminino através da urdidura de uma legião de "mulheres perdedoras". Mas a profundidade

33 BOSI, Alfredo. Literatura e resistência. São Paulo: Companhia das Letras, 2002, p. 120.

34 LECLAIRE, Serge. O país do outro: o inconsciente. Tradução de Clóvis Marques. Rio de Janeiro: Jorge Zahar, 1992, p. 28.

35

Op. cit., p. 63. 

DE LYA LUFT

polissêmica do romance, ao exibir personagens que se constroem/descontroem pelos efeitos da fala e da linguagem, aponta não somente para o encurralamento e a morbidez, mas para a vida que é sobretudo fugacidade, movimento, rastro luminoso do significante.

Anelise, a vacilante tecelã de elos, ao discorrer sobre a frouxa urdidura da vida, demonstra que, apesar do desejo que nos antecede/aprisiona, há outras formas de resistência que não a morte, sendo possível acreditar que

É a ardente busca das verdadeiras razões de viver através das trevas da ignorância, dos preconceitos, das mistificações, na luz vacilante e febril da paixão, é o risco infinito da felicidade ou da morte, da grandeza ou da vergonha que confere a estes destinos de mulher sua glória romanesca ${ }^{36}$.

As considerações acima apresentadas não esgotam o tema em questão, uma vez que uma obra literária é, irremediavelmente, inconquistável e inapreensível de todo. $\mathrm{Na}$ busca do subtexto do romance, conclui-se que Lya Luft, oriunda da terra de "míticos centauros", instala o seu traço de estilo (revelado por fragmentos, detalhes aparentemente insignificantes, indícios sutis), - pensando-se o estilo como uma escolha entre várias escrituras ${ }^{37}$-, ao apostar na arte literária como uma possibilidade de transformar em criação o que poderia ser morte/aniquilamento. Para finalizar, fiquemos com uma fala de Anelise: "bem junto de mim uma mulher. Tem o rosto na sombra, o sol às costas, a cabeça parece uma auréola. [...] Companheira de solidão, até que enfim" (p.149).

36 BEAUVOIR, Simone de. O segundo sexo. Op. cit., p. 291.

37 COMPAGNON, Antoine. O demônio da teoria. Op. cit., p. 194. 


\section{Referências}

BEAUVOIR, Simone de. O segundo sexo. Tradução de Sérgio Milliet. 2. ed. Rio de Janeiro: Nova Fronteira, 1980, vol. 1.

BOSI, Alfredo. Literatura e resistência. São Paulo: Companhia das Letras, 2002.

CANDIDO, Antonio. Literatura e sociedade: estudos de teoria e história literária. 7. ed. São Paulo: Nacional, 1985.

CHEMAMA, Roland (Org.). Dicionário de psicanálise. Tradução de Franke Settineri. Porto Alegre: Artes Médicas, 1993.

CHEVALIER, Jean \& GHEERBRANT, Alain. Dicionário de símbolos: mitos, sonhos, costumes, gestos, formas, figuras, cores, números. Tradução de Vera da Costa e Silva et al. 11. ed. Rio de Janeiro: José Olympio, 1997.

COMPAGNON, Antoine. O demônio da teoria: literatura e senso comum. Tradução de Cleonice Paes B. Mourão. Belo Horizonte: UFMG, 1999.

COMPAGNON, Antoine. O trabalho da citação. Tradução de Cleonice Paes B. Mourão. Belo Horizonte: UFMG, 1996.

CORRÊA, Ivan. A escrita do sintoma. Recife: CEF, 1997.

COSTA, Claudia de Lima. Sujeitos Ex/Cêntricos: explorando as fronteiras das teorias feministas. In: Fazendo gênero - Seminários de estudos sobre a mulher. Pós-graduação em Letras UFSC e Centro de Publicações UFPG, 1996, p. 51-59.

EAGLEATON, Terry. Teoria da literatura: uma introdução. Tradução de Waltensir Dutra. São Paulo: Martins Fontes, 1983.

FOUCAULT, Michel. O que é um autor? Tradução de Antônio Fernando Cascais e Edmundo Cordeiro. [s. 1.]: Veja, 1992.

FREUD, Sigmund. Obras completas de Sigmund Freud. Tradução de Jayme Salomão. Rio de Janeiro: Imago, ESB, 1976.

GROSZ, Elizabeth. Corpos reconfigurados. Cadernos Pagu, Campinas, SP, n. 14, p. 44-86. 
JULIEN, Philippe. A feminilidade velada: aliança conjugal e feminilidade. Tradução de Celso Pereira de Almeida. Rio de Janeiro: Companhia de Freud, 1997.

LACAN, Jacques. O eu na teoria de Freud e na técnica da psicanálise. Tradução de Marie C. L. Penot e Antônio Quinet. 4.ed. Rio de Janeiro: Jorge Zahar, 1995.

LACAN, Jacques. Os escritos técnicos de Freud. Tradução de Betty Milan. Rio de Janeiro: Jorge Zahar, 1994.

LECLAIRE, Serge. O país do outro: o inconsciente. Tradução de Clóvis Marques. Rio de Janeiro: Jorge Zahar, 1992.

LEMOINE-LUCCIONI, Eugènie. A mulher ... não-toda. Tradução de André Praga. Rio de Janeiro: Revinter, 1995.

LORAUX, Nicole. Maneiras trágicas de matar uma mulher imaginário da Grécia Antiga. Tradução de Mário da Gama Kury. Rio de Janeiro: Jorge Zahar, 1995.

LUFT, Lya. As parceiras. 11. ed. São Paulo: Siciliano, 1997.

LUFT, Lya. O rio do meio. 3. ed. São Paulo: Mandarim, 1996.

MACHADO, Roberto. Foucault, a filosofia e a literatura. Rio de Janeiro: Jorge Zahar, 2000.

MEICHES, Mauro. A travessia do trágico em análise. São Paulo: Casa do Psicólogo, 2000.

PASSOS, Cleusa R. Guimarães Rosa: do feminino e suas histórias. São Paulo: Hucitec; FAPESP,2000.

PAZ, Octavio. Signos em rotação. Tradução de Sebastião Uchoa Leite. São Paulo: Perspectiva, 1996.

PERRONE-MOISÉS, Leyla. Altas literaturas. São Paulo: Companhia das Letras, 1998.

SAFOUAN, Moustapha. A palavra ou a morte: como é possível uma sociedade humana? Tradução de Regina Steffen. São Paulo: Papirus, 1993.

SAFOUAN, Moustapha. Estudos sobre o Édipo: uma introdução a uma teoria do sujeito. Rio de Janeiro: Zahar Editores, 1974.

SCHÜLER, Donaldo. Heráclito e seu (dis)curso. Porto Alegre: L \& PM, 2000. 